\title{
Is Ventilator-associated Pneumonia a Misnomer? Need to Rephrase it for Better Understanding
}

\author{
Sunil K Garg ${ }^{1}$, Pragya Garg ${ }^{2}$ \\ Indian Journal of Critical Care Medicine (2019): 10.5005/jp-journals-10071-23299
}

One day while working in the intensive care unit, our infection control nurse asked me about a patient who developed pneumonia while he was intubated through orotracheal route. Patient was a case of hypertensive intracerebral bleed and he was intubated for airway protection in view of low Glasgow coma scale. He developed pneumonia while he was intubated, but was not put on mechanical ventilator. Later, he was placed on mechanical ventilation in view of increasing oxygen requirement due to pneumonia.

The infection control nurse asked me whether the patient developed pneumonia before or after initiation of mechanical ventilation because she wanted to know whether it was ventilatorassociated pneumonia (VAP). Her question was interesting since VAP is a confusing terminology for most of the healthcare workers and actually it has nothing to do with ventilator. It is important to understand that terminology becomes important since strategies to prevent VAP are likely to be successful if they are based upon a sound understanding of pathogenesis. ${ }^{1}$

In terms of pathophysiology, VAP is a misnomer because its occurrence is not related to ventilator per se but to the presence of endotracheal tube (ETT). The ETT allows direct access to the lower respiratory tract, impairing the cough reflex and mucociliary clearance, and provides incomplete sealing to secretions above the cuff. Microaspiration of colonized secretions from oropharyngeal cavities, sinuses, and gastrointestinal tract and biofilm formation are the two most important mechanisms in the development of VAP. ${ }^{2}$

The oropharynx becomes rapidly colonized by aerobic gramnegative bacteria after illness, antibiotic administration, and hospital admission. These contaminated secretions pool above the ETT cuff and slowly gain access to the lower airway through a
${ }^{1,2}$ Department of Critical Care, NMC Healthcare, Dubai, United Arab Emirates

Corresponding Author: Sunil K Garg, Department of Critical Care, NMC Healthcare, Dubai, United Arab Emirates, Phone: +971-521186920, e-mail: sucare12@yahoo.co.in

How to cite this article: Garg SK, Garg P. Is Ventilator-associated Pneumonia a Misnomer? Need to Rephrase it for Better Understanding. Indian J Crit Care Med 2019;23(12):593.

Source of support: Nil

Conflict of interest: None

fold in the wall of the cuff. A bacterial biofilm, which is impervious to antibiotics, gradually forms on the inner surface of the tube and serves as a nidus for infection. ${ }^{3}$

So it is important to understand that ETT is major contributor to VAP pathogenesis, not ventilator per se, since many of our patients are on ETT or tracheal tube without any ventilator support.

\section{References}

1. Safdar N, Crnich CJ, Maki DG. The pathogenesis of ventilatorassociated pneumonia: its relevance to developing effective strategies for prevention. Respir Care 2005;50(6):725-739.

2. Lau ACW, So HM, Tang SL, Yeung A, Lam SM, Yan WW. Prevention of ventilator-associated pneumonia. Hong Kong Med J 2015;21(1):61-68. DOI: $10.12809 / \mathrm{hkmj} 144367$.

3. Gunasekera P, Gratrix A. Ventilator-associated pneumonia. BJA Educ 2016;16(6):198-202. DOI: 10.1093/bjaed/mkv046.

(O) The Author(s). 20190pen Access This article is distributed under the terms of the Creative Commons Attribution 4.0 International License (https://creativecommons. org/licenses/by-nc/4.0/), which permits unrestricted use, distribution, and non-commercial reproduction in any medium, provided you give appropriate credit to the original author(s) and the source, provide a link to the Creative Commons license, and indicate if changes were made. The Creative Commons Public Domain Dedication waiver (http://creativecommons.org/publicdomain/zero/1.0/) applies to the data made available in this article, unless otherwise stated. 